\title{
Pre-pubertal exposure to high temperature impairs ovarian and adrenal gland function in female rats
}

\author{
Meihua ZHENG ${ }^{1,2)}$, Kentaro NAGAOKA ${ }^{1-3)}$ and Gen WATANABE ${ }^{1-3) *}$ \\ 1)United Graduate School of Veterinarian Sciences, Gifu University, 1-1 Yanagido, Gifu 501-1193, Japan \\ 2) Laboratory of Veterinary Physiology, Cooperative Department of Veterinary Medicine, Faculty of Agriculture, \\ Tokyo University of Agriculture and Technology, 3-5-8 Saiwai-cho, Fuchu, Tokyo 183-8509, Japan \\ ${ }^{3)}$ Cooperative Division of Veterinary Sciences (Doctoral Program), Graduate School of Agriculture, Tokyo \\ University of Agriculture and Technology, 3-5-8 Saiwai-cho, Fuchu, Tokyo 183-8509, Japan
}

J. Vet. Med. Sci.

81(2): 279-286, 2019

doi: 10.1292/jvms.18-0644

Received: 2 November 2018

Accepted: 9 December 2018

Published online in J-STAGE:

27 December 2018
ABSTRACT. The influence of different levels of heat exposure on the functions of ovarian and adrenal gland were investigated in pre-puberty female rats. Three-week old female rats were treated with control $\left(26^{\circ} \mathrm{C}\right)$ or three higher temperatures $\left(38,40\right.$ and $\left.42^{\circ} \mathrm{C}\right)$ for $2 \mathrm{hr} /$ day. After 9 days of treatment, blood samples were collected for measurement of luteinizing hormone (LH), follicle stimulating hormone (FSH), estradiol-17 $\beta$, corticosterone, cholesterol and triglyceride. Adrenal glands, ovaries and liver were collected for analyzing gene expressions. Body and liver weight were significantly low in the $42^{\circ} \mathrm{C}$ heating group. Circulating $\mathrm{LH}$ and triglyceride in the $42^{\circ} \mathrm{C}$ heating group were significantly lower, and estradiol-17 $\beta$, corticosterone and cholesterol were significantly higher than those of the control group. The gene expression of 3 $\beta$-HSD and P450c21 in the adrenal gland; $3 \beta-H S D$, receptors of $L H, F S H$ and estrogen in the ovary were significantly low in heated rats. The liver gene expressions of caspase 3 and NK-кB were significantly high in $42^{\circ} \mathrm{C}$ heated rats, suggesting that the ability of liver metabolic function reduced in the $42^{\circ} \mathrm{C}$ heated rats. These results demonstrated that the high temperature is responsible for suppression of ovarian function by decreasing the expression of steroidogenic enzymes, estrogen and gonadotropin receptors in the ovary. Increase in circulating estradiol- $17 \beta$ in the heated rats may be due to accumulate this hormone in circulation by potential changes in liver metabolism during the heat stress.

KEY WORDS: corticosterone, estradiol-17 $\beta$, heat stress, rat, steroidogenesis

Climate change due to global warming is a great concern with significant financial burden to animal production in most areas of the world. Over the past decades, effect of heat stress on the reproductive and immune system is well-represented in the literature $[3,10,14,19,31]$. It is the serious problem that high temperature suppresses gonadal function in both female and male domestic animals, so called "summer sterility". Although this phenomenon is the heat stress in animals, the endocrine mechanism is not clear. As the body's main regulator of stress, the hypothalamic-pituitary-adrenal axis (HPA axis) may be particularly important in this regard $[13,30]$. Corticosterone and cortisol, the endogenous main glucocorticoid, modulates homeostatic processes under basal and stress conditions, under the regulation of hypothalamic corticotropin-releasing hormone (CRH) from the hypothalamus and adrenocorticotropic hormone (ACTH) from the anterior pituitary gland [22].

The major role of the ovary is to produce oocytes for fertilization and to secrete reproductive hormones including estrogen, progesterone and inhibin that play a role in the estrous cycle and fertility. The ovarian function is controlled by gonadotropinreleasing hormone $(\mathrm{GnRH})$ secreted from hypothalamus which sends the messages to the anterior pituitary gland to stimulate secretion of luteinizing hormone (LH) and follicle stimulating hormone (FSH). FSH and LH act on the ovary and stimulate the expressions of steroidogenic enzymes in granulosa cells and theca cells to produce estrogen [20].

Previous papers reported the significant interaction between the HPA axis and the hypothalamic-pituitary-gonadal (HPG) axis [21]. The higher concentrations of cortisol suppressed LH secretion in heat stressed cows [7], rat primary pituitary cells cultured with high levels of corticosterone (10-100 Mm) resulted inhibitory effects on LH secretion at in vitro experiment [15]. Inconsistently, previous articles reported that unchanged or increased LH concentrations in peripheral blood in heat stressed cows $[8,9,23]$. These discrepancies may be associated with differences in sampling frequency, which varied from interval of sampling time and depend on whether stress is acute or chronic.

*Correspondence to: Watanabe, G.: gen@cc.tuat.ac.jp

O2019 The Japanese Society of Veterinary Science

This is an open-access article distributed under the terms of the Creative Commons Attribution Non-Commercial No Derivatives (by-nc-nd) License. (CC-BY-NC-ND 4.0: https://creativecommons.org/licenses/by-nc-nd/4.o/) 
The present study was conducted to evaluate ovarian and adrenal gland function under the hyperthermia environment in prepubertal female rats. The effect of different levels of heat exposure on the secretion of gonadotropins and steroid hormones, and the expression of steroidogenic enzymes in the adrenal gland, ovary and liver, and receptors of LH, FSH and estradiol-17 $\beta$ in the ovary were investigated.

\section{MATERIALS AND METHODS}

\section{Animals}

Twenty one days old female rats of the Wistar Imamichi strain (Imamich Institute for Animal Reproduction, Kasumigaura, Ibaraki, Japan), were used in this study. They were kept in the animal room of Laboratory of Veterinary Physiology at Tokyo University of Agriculture and Technology, maintained $26^{\circ} \mathrm{C}$ for control group, 38,40 and $42^{\circ} \mathrm{C}$ for heat-treated groups using Biomulti incubator (Nippon medical \& Chemical instrument Co., Ltd., Tokyo, Japan) under controlled lighting schedule (lights on 05:00-19:00 hr) and humidity $(50 \pm 10 \%)$. Food and water were available ad libitum. All animals were weighed on postnatal day 21 (PND21), 25 (PND25) and 30 (PND30). All procedures were carried out in accordance with the guidelines established by Tokyo University of Agriculture and Technology, for use of laboratory animals (No. 23-1).

\section{Experimental designs}

The control group was maintained at $26^{\circ} \mathrm{C}$, and the three different groups exposed to higher temperatures $\left(38,40\right.$ and $42^{\circ} \mathrm{C}$, respectively) from PND21 for $2 \mathrm{hr}(12: 00-14: 00 \mathrm{hr})$ per day $(\mathrm{N}=4)$. After 9-days of treatment, the animals were decapitated $30 \mathrm{~min}$ after the last heat exposure. All blood samples were collected into plastic tubes containing heparin $(15 \mathrm{IU} / \mathrm{m} l \mathrm{blood})$ as an anticoagulant to prevent clotting. The blood samples were stored on ice and centrifuged at $1,700 \mathrm{~g}$ for 15 min at $4^{\circ} \mathrm{C}$ immediately after the experiment was completed. The resulting plasma was stored at $-20^{\circ} \mathrm{C}$ until assayed for plasma hormones, and cholesterol and triglyceride. Adrenal glands and ovaries were collected for analyzing basal expression of steroidogenic enzymes and LH, FSH and estradiol- $17 \beta$ receptors by real time PCR. Another group of animals exposed in 26 and $42^{\circ} \mathrm{C}$ in same schedule were used for biological examination. Day of vaginal opening was observed, and vaginal smears were examined daily after vaginal opening until 80 days of age.

\section{Measurement of LH, FSH and corticosterone}

Plasma concentrations of LH and FSH were determined by homologous double-antibody rat radioimmunoassay (RIA) methods. Iodinated preparations were rat LH-I-7 and rat FSH-I-7, and the antisera were anti-rat LH-S-11 and anti-rat FSH-S-11, respectively. Results were expressed in terms of National Institute of Diabetes (NIDDK) rat LH-RP-3 and FSH-RP-2. The intra- and interassay coefficients of variation were 5.5 and $14.3 \%$ for $\mathrm{LH}$, and 6.7 and $13.8 \%$ for FSH.

Plasma concentrations of corticosterone was measured by double-antibody RIA system using ${ }^{125}$ I-labeled radioligand as described previously [17]. The antisera against corticosterone (GDN337) were kindly provided by Dr, G.D. Niswender (Colorado State University, Fort Collins, CO, U.S.A.). The intra- and interassy coefficient of variation were 8.9 and $14.6 \%$.

\section{Measurement of estradiol-17 $\beta$}

Plasma concentrations of estradiol-17 $\beta$ was determined by enzyme-linked immunosorbent assay using commercial kits (Item No.582251, Cayman Chemical Co., Ann Arbor, MI, U.S.A.).

\section{Measurement of cholesterol and triglyceride}

Plasma concentrations of cholesterol and triglyceride was determined by enzyme reaction using LabAssay ${ }^{\mathrm{TM}}$ Choleserol kit (Wako, Osaka, Japan) and LabAssay ${ }^{\mathrm{TM}}$ Triglyceride kit (Wako).

\section{$R N A$ extraction and $q R T-P C R$ analysis}

Total RNA was extracted from ovaries, adrenal glands and liver using Isogen II reagent kit (Nippon Gene, Tokyo, Japan). cDNA was generated using Primescript reverse transcriptase (Takara Bio, Kusatsu, Japan). The oligonucleotide primer for qRT-PCR analysis were designed using the Primer shown in Table 1. The PCR reaction were using Ex TaqR hot Start Version containing SYBR-Green I (Takara Bio). The temperature profile for the reactions was $95^{\circ} \mathrm{C}$ for $5 \mathrm{sec}, 60^{\circ} \mathrm{C}$ for $30 \mathrm{sec}$, and $40 \mathrm{cycles}$ consisting of $95^{\circ} \mathrm{C}$ for $5 \mathrm{sec}, 60^{\circ} \mathrm{C}$ for $30 \mathrm{sec}$. The expression level of each target mRNA relative to $\beta$-actin mRNA was determined using the $2^{-\triangle \Delta C T}$ method [26]. Relative expression was calculated by normalization to the mean of the $26^{\circ} \mathrm{C}$ control group.

\section{Statistical analysis}

The results shown in tables and figures are expressed as mean \pm SEM. Statistical analyses were performed using the GraphPad Prism 6 (Graphpad Software, Inc., La Jolla, CA, U.S.A.). Differences among experiment groups were evaluated using one-way analysis of variance (ANOVA) followed by Student's $t$-test. $P<0.05$ was considered as significant differences. 
Table 1. Nucleotitide sequences of the primers used for real-time PCR

\begin{tabular}{|c|c|c|}
\hline Genes name & Forward & Reverse \\
\hline StAR & 5'-GGGAGAGTGGAACCCAAATGT-3' & 5'-CATGGGTGATGACTGTGTCTTTTC-3' \\
\hline $\mathrm{P} 450 \mathrm{scc}$ & 5'-GGAGGAGATCGTGGAC-3 & 5'-TGGAGGCATGTTGAGC-3' \\
\hline $3 \beta \mathrm{HSD}$ & 5'-GGTGCAGGAAAGAA-3' & 5'-TGACATCAATGACAGC-3' \\
\hline $\mathrm{P} 450 \mathrm{c} 21$ & 5'-CCTCTCCATGGGGGAT-3' & 5'-CCAGCTGATAGTGACC-3' \\
\hline CYP17 $\alpha$ & 5'-TTTTGGCCCAAGTCAA-3' & 5'-AAGGTTGGCAGCTCTCATGT-3' \\
\hline $\mathrm{ER} \alpha$ & 5'-CATCGATAAGAACCGGAGGA-3' & 5'-AAGGTTGGCAGCTCTCATGT-3' \\
\hline FSHR & 5'-CTCATCTTTCССТCCA-3' & 5'-GGACTCATGCATCCCT-3' \\
\hline LHR & 5'-GCATTCAATGGGACGACTCT-3' & 5'-GTAGGAAGACAGGGCGATGA-3' \\
\hline $\mathrm{NF}-\kappa \mathrm{B}$ & 5'-CCGAGAAGGACCAATTGAAA-3' & 5'-AGAAGCCCTTTGCAAGTTCA-3' \\
\hline Caspase 3 & 5'-TCATCATGCCCACTTCGTAA-3' & 5'-GCTACGATCCACCAGCATTT-3' \\
\hline GAPDH & 5'-CCTGCCCAAGATTGTTGAGT-3' & 5'-TGTACCGATCGATGTCTGGA-3' \\
\hline$\beta$-Actin & 5'-AGCCATGTACGTAGCCATCC-3' & 5'-CTCTCAGCTGTGGTGGTGAA-3' \\
\hline
\end{tabular}

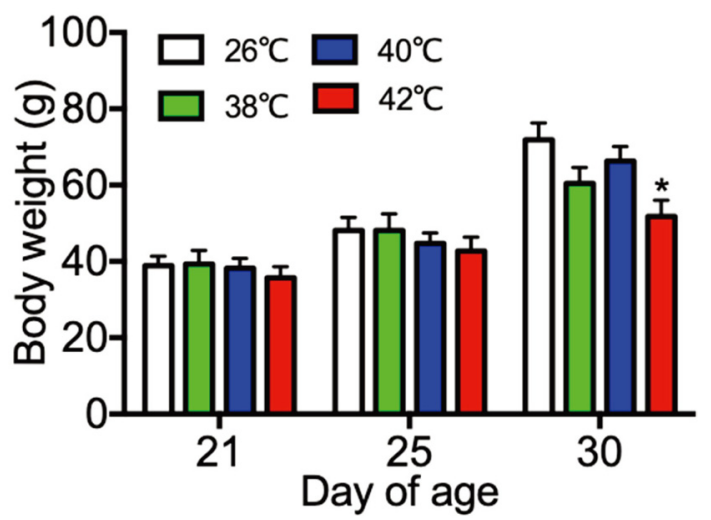

Fig. 1. Body weight of control $\left(26^{\circ} \mathrm{C}\right)$ and heat treated immature female rats $\left(38,40,42^{\circ} \mathrm{C}\right)$ at 21,25 and 30 day of age. Each bar represents mean \pm S.E.M. of 4 rats. Asterisks indicate significant difference compared to the control. $* P<0.05$.

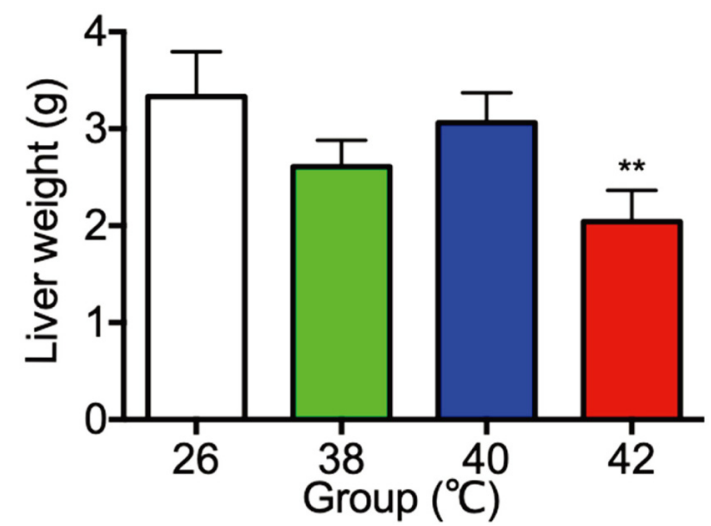

Fig. 2. The liver weight of control $\left(26^{\circ} \mathrm{C}\right)$ and heat treated immature female rats $\left(38,40,42^{\circ} \mathrm{C}\right)$ at 30 day of age. Each bar represents mean \pm S.E.M. of 4 rats. Asterisks indicate significant difference compared to the control. ${ }^{* *} P<0.01$.

\section{RESULTS}

\section{Body weights and organs weights}

Body weights and liver weights under different temperature treatments were shown in Figs. 1 and 2. The body and liver weights on PND30 were significantly low in the $42^{\circ} \mathrm{C}$ heat treated rats as compared with the $26^{\circ} \mathrm{C}$ control group. There were no significant different in the weights of ovaries, adrenal glands, spleens, kidneys and thymus among the $26^{\circ} \mathrm{C}$ control group and the heat treated groups (data not shown).

\section{Plasma concentrations of LH, FSH, estradiol-17 $\beta$, corticosterone and cholesterol}

Plasma concentrations of LH, FSH, estradiol-17 $\beta$, corticosterone and cholesterol on PND30 were shown in Fig. 3. Plasma concentrations of $\mathrm{LH}$ in the $42^{\circ} \mathrm{C}$ heat treated rats were significanty lower than the $26^{\circ} \mathrm{C}$ control rats (Fig. 3a), whereas plasma concentrations of FSH were no difference among four groups (Fig. 3b). Plasma concentrations of estradiol-17 $\beta$ and corticosterone were significantly higher in the $42^{\circ} \mathrm{C}$ heat treated rats than the $26^{\circ} \mathrm{C}$ control rats (Fig. $3 \mathrm{c}, 3 \mathrm{~d}$ ). Moreover, plasma concentrations of cholesterol were significantly higher in the 38,40 and $42^{\circ} \mathrm{C}$ heat treated rats than the $26^{\circ} \mathrm{C}$ control rats (Fig. $3 \mathrm{e}$ ).

\section{Gene expression of StAR and steroidogenic enzymes in adrenal glands}

Adrenal gland gene expression of StAR and steroidogenic enzymes including P450scc, 3 $\beta$-HSD and P450c21 were shown in Fig. 4. Expression of StAR in the 38 and $40^{\circ} \mathrm{C}$ heat treated rats were significantly lower than the $26^{\circ} \mathrm{C}$ control rats (Fig. $4 \mathrm{a}$ ). Expression of $\mathrm{P} 450 \mathrm{scc}$ in the $42^{\circ} \mathrm{C}$ heat treated rats were significantly higher than the $26^{\circ} \mathrm{C}$ control rats (Fig. $4 \mathrm{~b}$ ). Expression of $3 \beta$-HSD in the $42^{\circ} \mathrm{C}$ heat treated rats were significantly lower than the $26^{\circ} \mathrm{C}$ control rats (Fig. $4 \mathrm{c}$ ). Expression of $\mathrm{P} 450 \mathrm{c} 21$ in the $38,40^{\circ} \mathrm{C}$ and $42^{\circ} \mathrm{C}$ heat treated rats were significantly lower than the $26^{\circ} \mathrm{C}$ control rats (Fig. $4 \mathrm{~d}$ ). 

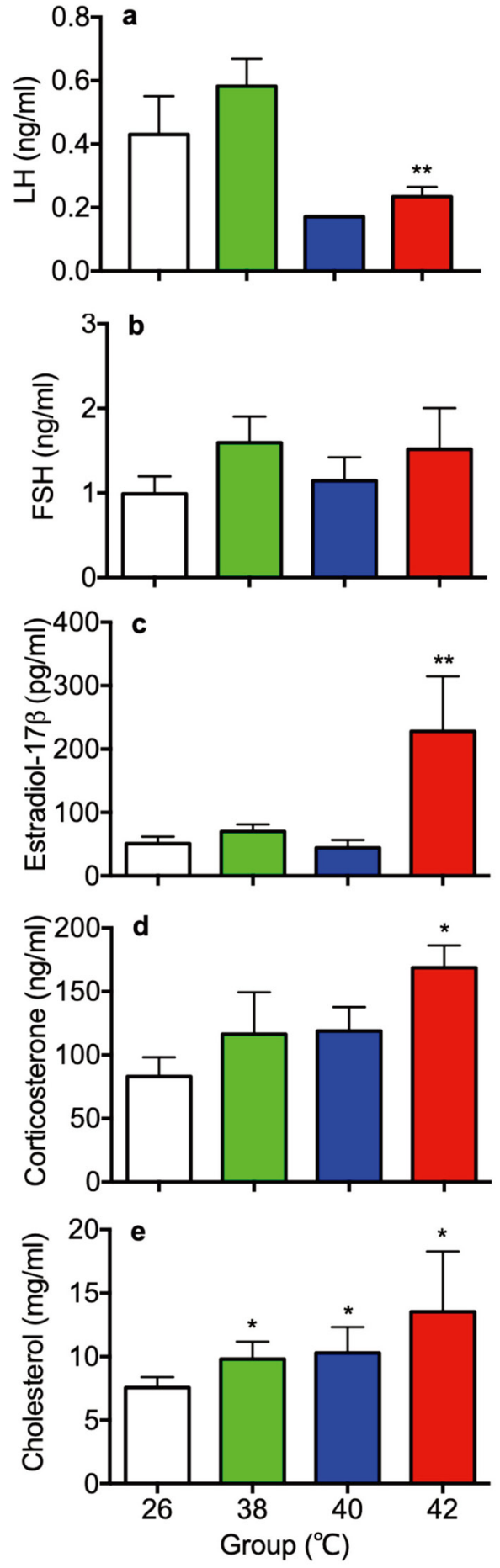

Fig. 3. Plasma concentrations of luteinizing hormone (LH;a), folliclestimulating hormone (FSH; b), estradiol-17 $\beta$ (c), corticosterone (d) and cholesterol (e) of control $\left(26^{\circ} \mathrm{C}\right)$ and heat treated immature female rats $\left(38,40,42^{\circ} \mathrm{C}\right)$ at 30 day of age. Each bar represents mean \pm S.E.M. of 4 rats except $40^{\circ} \mathrm{C}$ treated rats in the panel a $(\mathrm{n}=2)$. Asterisks indicate significant difference compared to the control. $* P<0.05 ; * * P<0.01$.
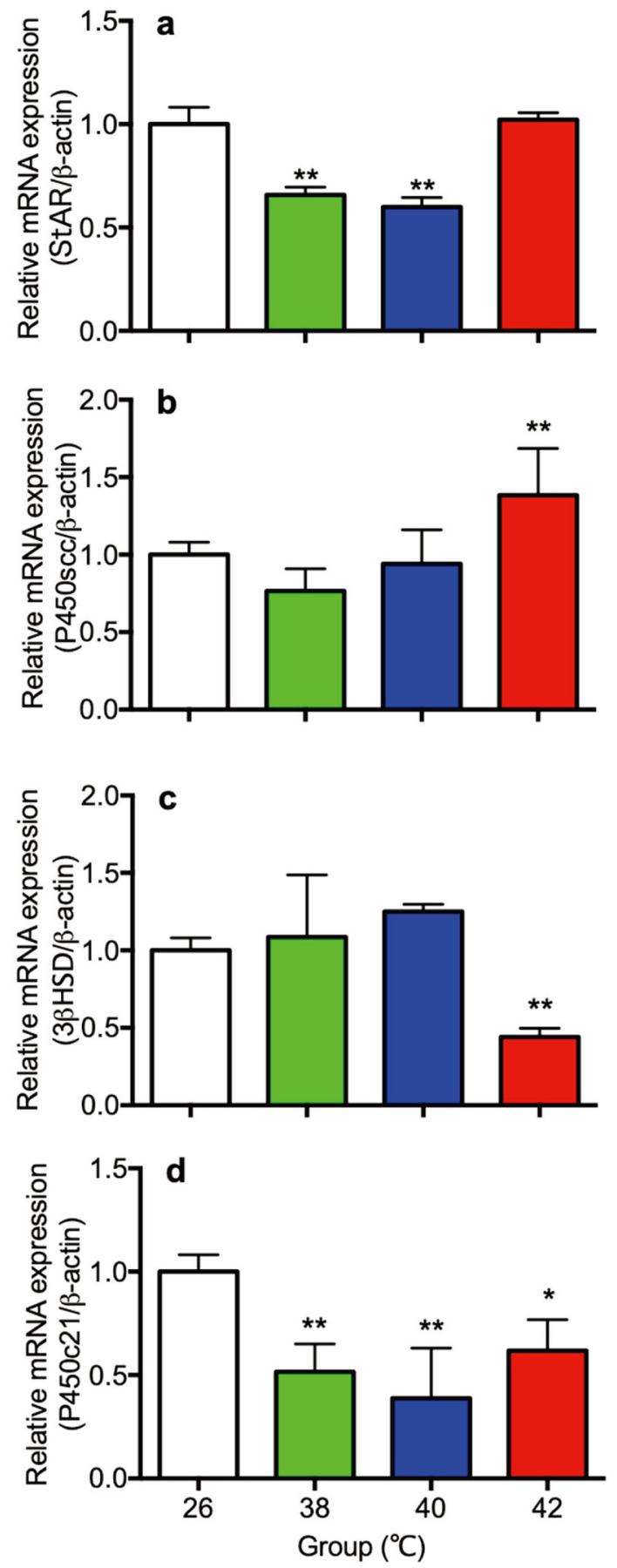

Fig. 4. The gene expression of StAR (a) steroidogenic enzymes P450scc (b), 3ß-HSD (c) and P450c21 (d) in the adrenal gland of control $\left(26^{\circ} \mathrm{C}\right)$ and heat treated immature female rats $(38$, $40,42^{\circ} \mathrm{C}$ ) at 30 day of age. Each bar represents mean \pm S.E.M. of 4 rats. Asterisks indicate significant difference compared to the control $(* P<0.05$ and $* * P<0.01)$. 

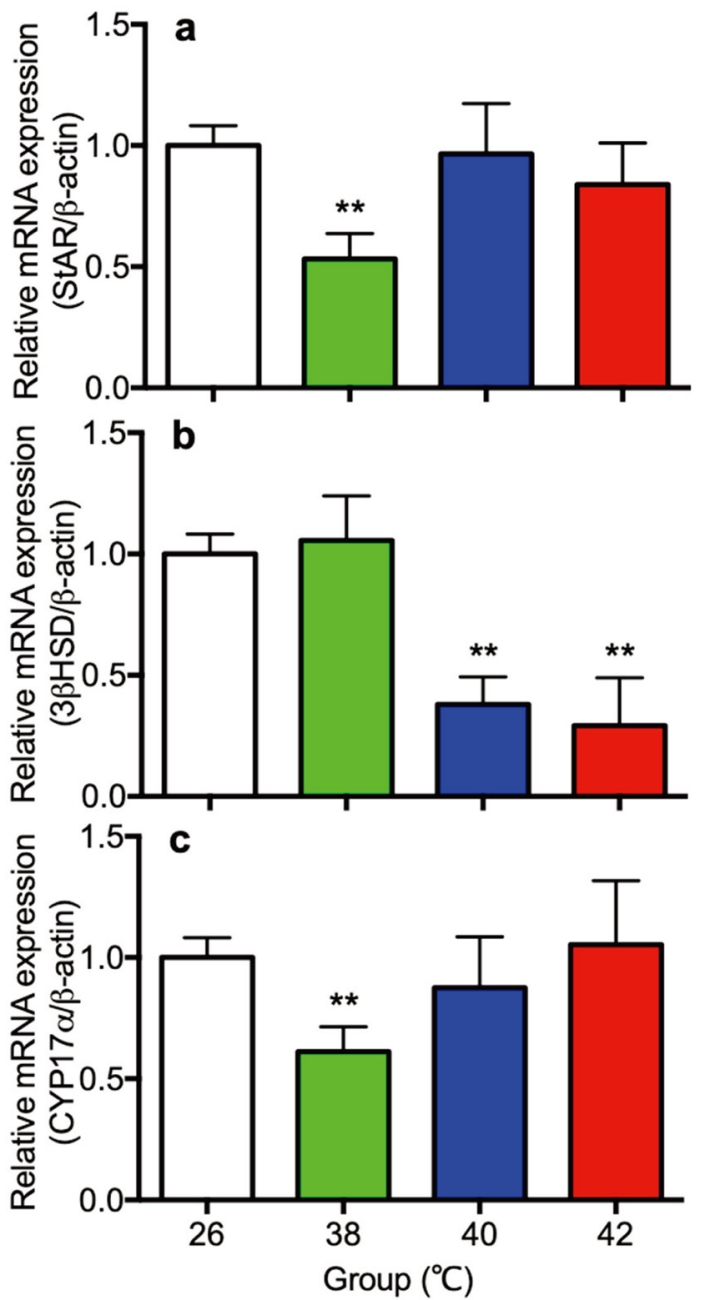

Fig. 5. The gene expression of StAR (a) steroidogenic enzymes $3 \beta$-HSD (b) and CYP17 $\alpha$ (c) in the ovary of control $\left(26^{\circ} \mathrm{C}\right)$ and heat treated immature female rats $\left(38,40,42^{\circ} \mathrm{C}\right)$ at 30 day of age. Each bar represents mean \pm S.E.M. of 4 rats. Asterisks indicate significant difference compared to the control $(* P<0.05$ and $* * P<0.01)$.
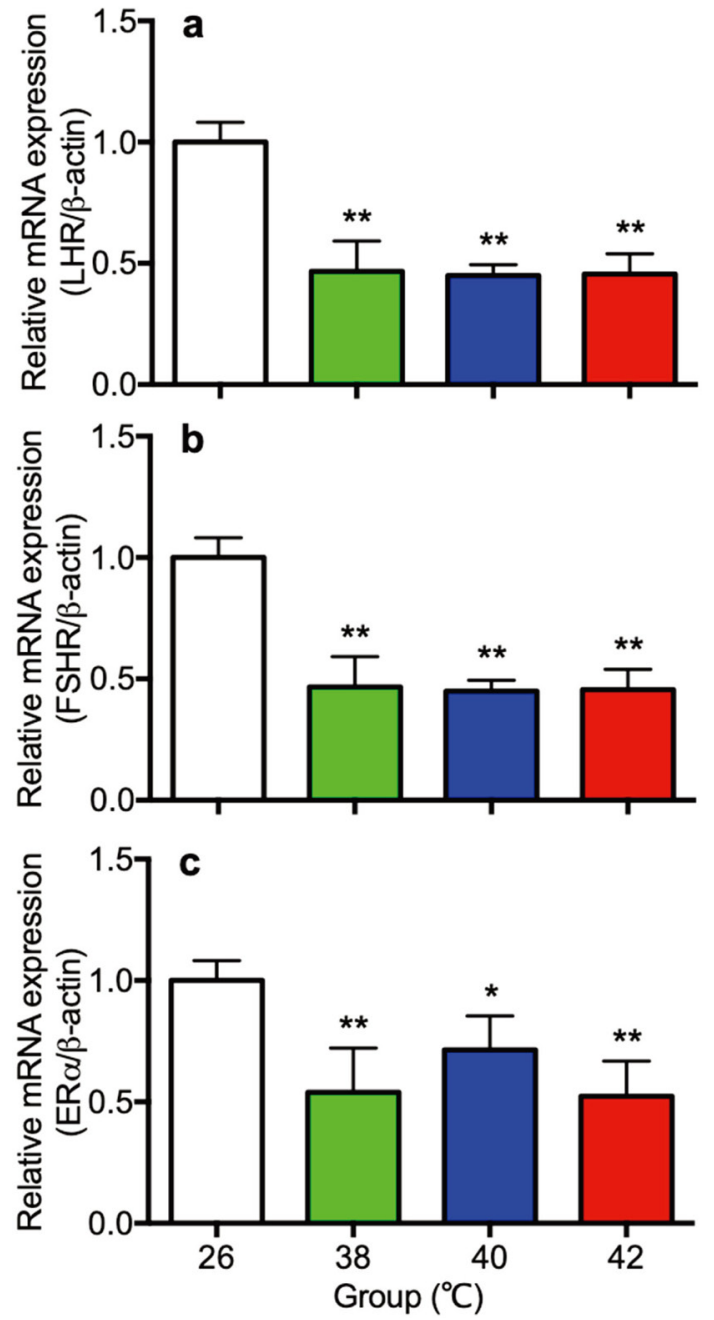

Fig. 6. The gene expression of receptor of LH (LHR: a), FSH (FSHR:b) and estrogen (ER:c) in the ovary of control $\left(26^{\circ} \mathrm{C}\right)$ and heat treated immature female rats $(38$, $40,42^{\circ} \mathrm{C}$ ) at 30 day of age. Each bar represents mean \pm S.E.M. of 4 rats. Asterisks indicate significant difference compared to the control $(* P<0.05$ and $* * P<0.01)$.

Gene expression of StAR and steroidogenic enzymes in ovaries

Gene expression of StAR, 3 3 -HSD and CYP17 $\alpha$ were shown in Fig. 5. Expression of StAR in the $38^{\circ} \mathrm{C}$ heat treated rats (Fig. 5a), $3 \beta$-HSD in the 40 and $42^{\circ} \mathrm{C}$ heat treated rats (Fig. 5b), and CYP $17 \alpha$ in the $38^{\circ} \mathrm{C}$ heat treated rats (Fig. $5 \mathrm{c}$ ) were significantly lower than the $26^{\circ} \mathrm{C}$ control rats.

Gene expression of receptors of LH (LHR), FSH (FSHR) and estrogen (ER $\alpha$ ) in ovaries

Gene expression of LHR, FSHR and ER $\alpha$ in ovaries were shown in Fig. 6. Expression of LHR, FSHR and ER $\alpha$ in ovaries in the 38,40 and $42^{\circ} \mathrm{C}$ heat treated rats (Fig. $6 \mathrm{a}-\mathrm{c}$ ) were significantly lower than the $26^{\circ} \mathrm{C}$ control rats.

Gene expression of caspase 3 and $N K-\kappa B$ in liver

Gene expression of Caspase 3 and NK-KB in liver were shown in Fig. 7. Expression of caspase 3 in the $42^{\circ} \mathrm{C}$ (Fig. 7a), and NK- $\mathrm{kB}$ in the $40^{\circ} \mathrm{C}$ and the $42^{\circ} \mathrm{C}$ heat treated rats (Fig. 7b) in the liver were significantly higher than the $26^{\circ} \mathrm{C}$ control rats.

\section{Plasma concentrations of triglyceride}

Plasma concentrations of triglyceride in the $26^{\circ} \mathrm{C}$ control rats and the $42^{\circ} \mathrm{C}$ heat treated rats were shown in Fig. 8. Plasma concentrations of triglyceride in the $42^{\circ} \mathrm{C}$ heat treated rats were significant low as compared with the $26^{\circ} \mathrm{C}$ control rats. 

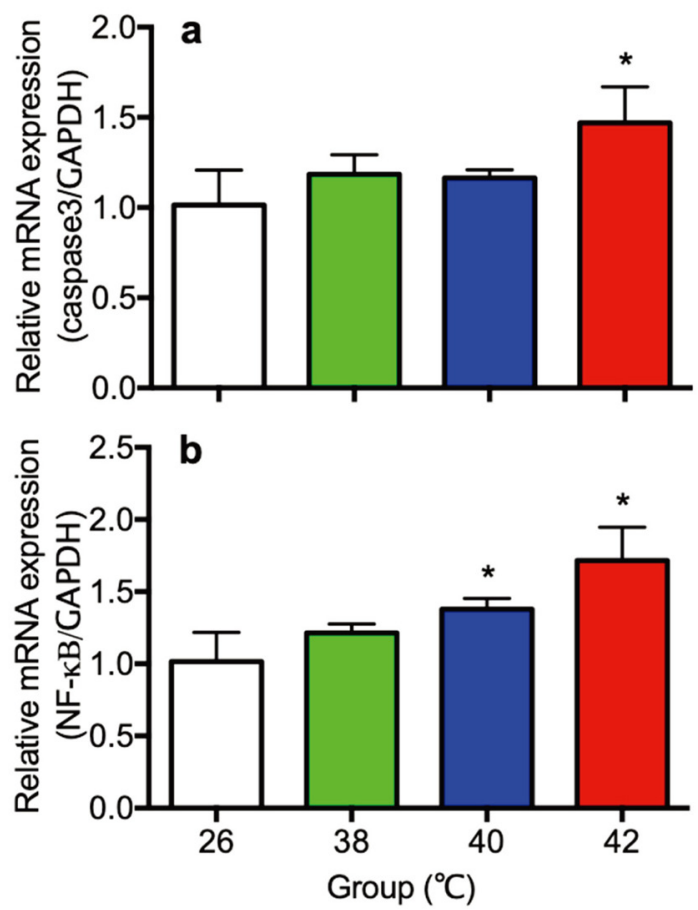

Fig. 7. The gene expression of Caspase 3 (a) and NK$\kappa \mathrm{B}(\mathrm{b})$ in liver of control $\left(26^{\circ} \mathrm{C}\right)$ and heat treated immature female rats $\left(38,40,42^{\circ} \mathrm{C}\right)$ at 30 day of age. Each bar represents mean \pm S.E.M. of 4 rats. Asterisks indicate significant difference compared to the control $(* P<0.05)$

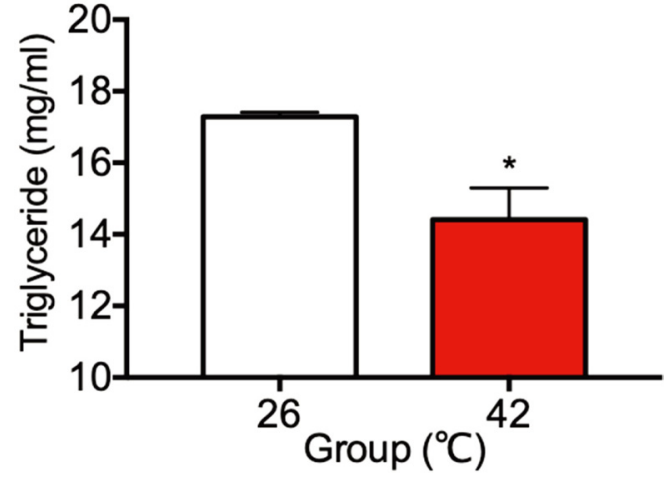

Fig. 8. Plasma concentrations of triglyceride in the $26^{\circ} \mathrm{C}$ control rats and the $42^{\circ} \mathrm{C}$ heat treated rats at 30 day of age. Each bar represents mean \pm S.E.M. of 4 rats. Asterisks indicate significant difference compared to the control $\left({ }^{*} P<0.05\right)$.

Table 2. Vaginal opening and estrous cycle

\begin{tabular}{ccc}
\hline Group & Vaginal opening & Estrous cycle \\
\hline $26^{\circ} \mathrm{C}$ & $34.4 \pm 0.2$ & $38.8 \pm 0.9$ \\
$42^{\circ} \mathrm{C}$ & $37.0 \pm 0.0^{\text {a) }}$ & $48.8 \pm 0.7^{\mathrm{a})}$ \\
\hline
\end{tabular}

Result are expressed as mean \pm S.E.M. $(n=5)$. a) Significant difference between $26^{\circ} \mathrm{C}$ group and $42^{\circ} \mathrm{C}$ group.

\section{Vaginal opening and estrous cycle}

Day of vaginal opening and estrous cycle after vaginal opening were shown in Table 2. Day of vaginal opening in the $42^{\circ} \mathrm{C}$ heat treated rats were significant delayed as compared with the $26^{\circ} \mathrm{C}$ control rats. Day of age at starting 4-day estrous cycle in the $42^{\circ} \mathrm{C}$ heat treated rats were significant delayed as compared with the $26^{\circ} \mathrm{C}$ control rats.

\section{DISCUSSION}

The global warming is a worldwide serious problem in the livestock production. The suppression of gonadal function occurred in both female and male animals during summer season. This phenomenon is the heat stress, and heat stress affects fertility, immunity, and endocrine function as observed in the dairy cow $[1,11,24,28]$. However, the mechanism of heat stress is still unclear. To clarify the mechanism of heat stress on the ovarian and adrenal function, pre-pubertal female rats were treated with three different levels of heat in the present study. The present study clearly demonstrated that high temperature caused liver damage and lipid metabolic in the immature female rat.

In the present study, immature female rats exposed to heat stress during the pre-pubertal period (PND 21-30) had reduction of circulating LH, and ovarian gene expression of LH, FSH and estrogen receptors. The lower LHR and FSHR gene expression may be due to decreased secretion of LH and FSH from pituitary to the theca cells and granulosa cells, this in turn could suppress ovarian follicular development and estradiol-17 $\beta$ secretion. The present study demonstrated that day of vaginal opening and start of estrous cycle delayed in the $42^{\circ} \mathrm{C}$ heat treated rats. These results suggest that the heat stress in the present study suppressed ovarian follicular maturation in the pre-pubertal female rat. Previous studies reported that heat stress induced low concentration of estradiol-17 $\beta$ in follicular fluids in cows $[4,32]$. The decline of circulating LH and the gene expression of StAR and steroidogenic enzymes $3 \beta \mathrm{HSD}$ and CYP17, seen in the present study could support decrease secretion of estradiol-17 $\beta$ in the ovary. Unexpectedly, however, the plasma concentration of estradiol- $17 \beta$ dramatically increased in $42^{\circ} \mathrm{C}$ heat treated rats in the present study. Concentrations of estradiol- $17 \beta$ in circulation in the $42^{\circ} \mathrm{C}$ heat treated rats were much higher than those of the day of proestrous in cyclic female rats $(127.7 \pm 12.1 ; n=4)$. These results may be due to decreased liver metabolic function in the $42^{\circ} \mathrm{C}$ heat treated rats. The present study clearly demonstrated that liver weight significantly decreased in the $42^{\circ} \mathrm{C}$ heated rats, and expression of caspase 3 in the $42^{\circ} \mathrm{C}$ and NK- $\mathrm{kB}$ in the $40^{\circ} \mathrm{C}$ and the $42^{\circ} \mathrm{C}$ heat treated rat in the liver were significantly increased. In addition, plasma concentrations of triglyceride in the $42^{\circ} \mathrm{C}$ heat treated rats significant decreased. These results strongly suggested that the ability of liver metabolic function reduced in heat treated rats. Therefore, estradiol-17 $\beta$ were accumulated in 
circulation, this in turn suppression of LH secretion by negative feedback effect of estradiol-17 $\beta$ on the hypothalamus-pituitary axis. In the preliminary experiment, observation of liver histopathology of these same rats suggest structural abnormalities in the $42^{\circ} \mathrm{C}$ heated rats (data not shown). Similar result was found by another group in heat treated rats [2], in which the hepatic cells around the hepatic vein developed hypertrophy to a great extent, and vacuolated degeneration under the hot environment. On the other hand, there is a discrepancy that the day of vaginal opening delayed in the $42^{\circ} \mathrm{C}$ heated rats, whereas circulating estradiol- $17 \beta$ are higher than adult female rats. The exact mechanism is not clear at the present time, the amount of $\alpha$-fetoprotein in circulation may be related, because the liver function decreased in the $42^{\circ} \mathrm{C}$ heated rats. Further studies will be required to demonstrate this discrepancy.

The HPA axis was also activated by heat stress. Plasma concentrations of corticosterone were significantly increased in $42^{\circ} \mathrm{C}$ heat treated group in the present study. These results consistent with previous findings in pigs [33]. The mechanisms involved in the change of corticosterone might be the expression levels of StAR and steroidogenic enzymes in adrenal gland. The present study showed significantly increased $\mathrm{P} 450 \mathrm{scc}$ in $42^{\circ} \mathrm{C}$ heated rats, and significantly decreased expression of $\mathrm{StAR}$ in $38^{\circ} \mathrm{C}$ and $40^{\circ} \mathrm{C}$, $3 \beta$-HSD in $42^{\circ} \mathrm{C}$, and $\mathrm{P} 450 \mathrm{c} 21$ in all heat treated rats. These results indicate that heat treatment increases adrenal response capacity of corticosterone by enhancing the expression levels of steroidogenic enzyme P450scc in pre-pubertal female rats.

Previous study clearly demonstrated that the acute restraint stress rapidly increased the activity of the hypothalamus-pituitaryadrenal axis, whereas hypothalamus-pituitary-gonadal axis activity decreased in male rats [25]. Restraint stress induced a significant elevation in plasma adrenocorticotropic hormone (ACTH), prolactin, corticosterone and progesterone, and decreased FSH, LH, testosterone and immunoreactive (ir-) inhibin in the male rat. Previous papers demonstrated that the stress suppressed the secretion of both LH and FSH, and this effect is mediated by the inhibition of Kisspeptin and GnRH secretion from the hypothalamus [18]. Previous studies also suggested that the stress-induced inhibition of Kisspeptin and GnRH may be primary mediated by endogenous CRH and opioid peptides. [18, 27, 29]. Growing evidence indicated that gonadotropin inhibitory hormone $(\mathrm{GnIH})$ also play pivotal roles in the stress-induced disruption of the hypothalamus-pituitary-gonadal axis $[5,12]$.

Previous studies reported that heat stress increased plasma levels of cholesterol and decreased body weight (or/and feed intake) in human [16] and rats [6]. Consistent with that evidence, the present study also showed elevated plasma cholesterol in all heattreated rats and decreased body weight in $42^{\circ} \mathrm{C}$ treated rats. Although food intake was not measured in the present study, the decreased body weight in $42^{\circ} \mathrm{C}$ heat exposed rats indicates that the feed intake might decreased in this experiment, which may also relate to the increased plasma level of cholesterol in heated rats because lower feed intake leads to a net increase in endogenous production of cholesterol, whereas higher intake from food has the opposite effect. Higher concentrations of corticosterone in $42^{\circ} \mathrm{C}$ heated rats may relate to the increased cholesterol, since cholesterol is a precursor molecule for several biochemical, including corticosterone.

In summary, the results of the present study may thus indicate that (1) the high temperature is responsible for suppression of ovarian function by decreasing the expression of steroidogenic enzymes, estrogen and gonadotropin receptors in the ovaries; (2) the heat treatment increase concentrations of estradiol-17 $\beta$ in plasma may be due to accumulate this hormone in circulation by potential changes in liver metabolism during the heat stress; (3) the high temperature is also responsible for suppression the hypothalamuspituitary axis by central mechanisms. It is, therefore, possible that the present study adds new knowledge about effects of heat on stress responses and the reproductive system in pre-pubertal animals.

ACKNOWLEDGMENTS. We are grateful to the National Hormone and Pituitary Program, NIDDK, National Institutes of Health, and Dr. A. F. Parlow for rat LH and FSHRIA kits. We are also grateful to Dr. G. D. Niswender (Animal Reproduction and Biotechnology Laboratory, Colorado State University, Fort Collins, CO, U.S.A.) for providing anti-corticosterone (GDN 377).

\section{REFERENCES}

1. al-Katanani, Y. M., Webb, D. W. and Hansen, P. J. 1999. Factors affecting seasonal variation in 90-day nonreturn rate to first service in lactating Holstein cows in a hot climate. J. Dairy Sci. 82: 2611-2616. [Medline] [CrossRef]

2. Ando, M., Katagiri, K., Yamamoto, S., Wakamatsu, K., Kawahara, I., Asanuma, S., Usuda, M. and Sasaki, K. 1997. Age-related effects of heat stress on protective enzymes for peroxides and microsomal monooxygenase in rat liver. Environ. Health Perspect. 105: 726-733. [Medline]

3. Black, J. L., Mullan, B. P., Lorschy, M. L. and Giles, L. R. 1993. Lactation in the sow during heat stress. Livest. Prod. Sci. 35: 153-170. [CrossRef]

4. Bridges, P. J., Brusie, M. A. and Fortune, J. E. 2005. Elevated temperature (heat stress) in vitro reduces androstenedione and estradiol and increases progesterone secretion by follicular cells from bovine dominant follicles. Domest. Anim. Endocrinol. 29: 508-522. [Medline] [CrossRef]

5. Clarke, I. J., Bartolini, D., Conductier, G. and Henry, B. A. 2016. Stress increases gnadotropin inhibitory hormone cell activity and input to GnRH cells in ewes. Endocrinology 157: 4339-4350. [Medline] [CrossRef]

6. Djordjević, J., Cvijić, G. and Davidović, V. 2003. Different activation of ACTH and corticosterone release in response to various stressors in rats. Physiol. Res. 52: 67-72. [Medline]

7. Gangwar, P. C., Branton, C. and Evans, D. L. 1965. Reproductive and physiological response of Holstein heifers to controlled and natural climatic conditions. J. Dairy Sci. 48: 222-227. [Medline] [CrossRef]

8. Gauthier, D. 1986. The influence of season and shade on oestrous behaviour, timing of preovulatory LH surge and the pattern of progesterone secretion in FFPN and Creole heifers in a tropical climate. Reprod. Nutr. Dev. 26: 767-775. [Medline] [CrossRef]

9. Gwazdauskas, F. C., Thatcher, W. W., Kiddy, C. A., Paape, M. J. and Wilcox, C. J. 1981. Hormonal patterns during heat stress following PGF(2) alpha-tham salt induced luteal regression in heifers. Theriogenology 16: 271-285. [Medline] [CrossRef]

10. Hansen, P. J. 2009. Effects of heat stress on mammalian reproduction. Philos. Trans. R. Soc. Lond. B Biol. Sci. 364: 3341-3350. [Medline] [CrossRef] 
11. Ingraham, R. H., Gillette, D. D. and Wagner, W. D. 1974. Relationship of temperature and humidity to conception rate of Holstein cows in subtropical climate. J. Dairy Sci. 57: 476-481. [Medline] [CrossRef]

12. Iwasa, T., Matsuzaki, T., Yano, K., Mayila, Y. and Irahara, M. 2018. The roles of kisspeptin and gonadotropin inhibitory hormone in stress-induced reproductive disorders. Endocr. J. 65: 133-140. [Medline] [CrossRef]

13. Joseph, D. N. and Whirledge, S. 2017. Stress and the HPA axis: Balancing homeostasis and fertility. Int. J. Mol. Sci. 18: 2224. [Medline] [CrossRef]

14. Jordan, E. R. 2003. Effects of heat stress on reproduction. J. Dairy Sci. 86: E104-E114. [CrossRef]

15. Kamel, F. and Kubajak, C. L. 1987. Modulation of gonadotropin secretion by corticosterone: interaction with gonadal steroids and mechanism of action. Endocrinology 121: 561-568. [Medline] [CrossRef]

16. Keatinge, W. R., Coleshaw, S. R., Easton, J. C., Cotter, F., Mattock, M. B. and Chelliah, R. 1986. Increased platelet and red cell counts, blood viscosity, and plasma cholesterol levels during heat stress, and mortality from coronary and cerebral thrombosis. Am. J. Med. 81: 795-800. [Medline] [CrossRef]

17. Kanesaka, T., Taya, K. and Sasamoto, S. 1992. Radioimmunoassay of corticosterone using ${ }^{123}$ I-labeled radioligand. J. Reprod. Dev. 38: 85-89. [CrossRef]

18. Luo, L., Wang, Y., Deng, D., Cheng, Y. and Zhou, H. 2016. Effects of light stress on the expression of Kisspeptin/GnRH in rat hypothalamus. Int. J. Clin. Exp. Med. 9: 16964-16970.

19. Marai, I. F. M., El-Darawany, A. A., Fadiel, A. and Abdel-Hafez, M. A. M. 2007. Physiological traits as affected by heat stress in sheep-A review. Small Rumin. Res. 71: 1-12. [CrossRef]

20. Meethal, S.V., Liu, T., Chan, H.W., Ginsbrg, E., Wilson, A.C., Gray, D.N., Bowen, R.L., Vonderhaar, B.K. and Atwood, C.S. 2009. Identification of a regulatory loop for the synthesis of neurosteroids: a steroidogenic acute regulatory protein-dependent mechanism involving hypothalamicpituitary-gonadal axis receptors. J. Neurochem. 110: 1014-1027. 21. [Medline]

21. Oyola, M. G. and Handa, R. J. 2017. Hypothalamic-pituitary-adrenal and hypothalamic-pituitary-gonadal axes: sex differences in regulation of stress responsivity. Stress 20: 476-494. [Medline] [CrossRef]

22. Pariante, C. M. and Lightman, S. L. 2008. The HPA axis in major depression: classical theories and new developments. Trends Neurosci. 31: 464-468. [Medline] [CrossRef]

23. Roman-Ponce, H., Thatcher, W. W. and Wilcox, C. J. 1981. Hormonal interelationships and physiological responses of lactating dairy cows to a shade management system in a subtropical environment. Theriogenology 16: 139-154. [Medline] [CrossRef]

24. Ray, D. E., Halbach, T. J. and Armstrong, D. V. 1992. Season and lactation number effects on milk production and reproduction of dairy cattle in Arizona. J. Dairy Sci. 75: 2976-2983. [Medline] [CrossRef]

25. Ren, L., Li, X., Weng, Q., Trisomboon, H., Yamamoto, T., Pan, L., Watanabe, G. and Taya, K. 2010. Effects of acute restraint stress on sperm motility and secretion of pituitary, adrenocortical and gonadal hormones in adult male rats. J. Vet. Med. Sci. 72: 1501-1506. [Medline] [CrossRef]

26. Schmittgen, T. D. and Livak, K. J. 2008. Analyzing real-time PCR data by the comparative C(T) method. Nat. Protoc. 3: 1101-1108. [Medline] [CrossRef]

27. Taya, K. and Sasamoto, S. 1989. Inhibitory effects of corticotrophin-releasing factor and $\beta$-endorphin on LH and FSH secretion in the lactating rat. J. Endocrinol. 120: 509-515. [Medline] [CrossRef]

28. Thompson, J. A., Magee, D. D., Tomaszewski, M. A., Wilks, D. L. and Fourdraine, R. H. 1996. Management of summer infertility in Texas Holstein dairy cattle. Theriogenology 46: 547-558. [Medline] [CrossRef]

29. Tohei, A., Tomabechi, T., Mamada, M., Akai, M., Watanabe, G. and Taya, K. 2001. Immunoneutralization of endogenous corticotropin releasing hormone (CRH) blocks the suppression of luteinizing hormone (LH) secretion induced by adrenalectomy and restained stress. J. Reprod. Dev. 47: 211-216. [CrossRef]

30. Webster Marketon, J. I. and Glaser, R. 2008. Stress hormones and immune function. Cell. Immunol. 252: 16-26. [Medline] [CrossRef]

31. Wettemann, R. P. and Bazer, F. W. 1985. Influence of environmental temperature on prolificacy of pigs. J. Reprod. Fertil. Suppl. 33: $199-208$. [Medline]

32. Wolfenson, D., Lew, B. J., Thatcher, W. W., Graber, Y. and Meidan, R. 1997. Seasonal and acute heat stress effects on steroid production by dominant follicles in cows. Anim. Reprod. Sci. 47: 9-19. [Medline] [CrossRef]

33. Yu, J., Yin, P., Liu, F., Cheng, G., Guo, K., Lu, A., Zhu, X., Luan, W. and Xu, J. 2010. Effect of heat stress on the porcine small intestine: a morphological and gene expression study. Comp. Biochem. Physiol. A Mol. Integr. Physiol. 156: 119-128. [Medline] [CrossRef] 